\title{
EFFECT OF POSTURAL BALANCE ON CHANGES IN THE ELECTROCARDIOGRAPHY PARAMETERS OF WRESTLERS
}

\author{
V.V. Erlikh1, erlikhvv@susu.ru, ORCID: 0000-0003-4416-1925, \\ Yu.B. Korableva ${ }^{1}$, julya-74@yandex.ru, ORCID: 0000-0003-2337-3531, \\ V.V. Epishev1, epishev74@mail.ru, ORCID: 0000-0002-7284-7388, \\ O. Polyakova², O.Polyakova@shu.ac.uk, ORCID: 0000-0002-6947-2394 \\ ${ }^{1}$ South Ural State University, Chelyabinsk, Russian Federation, \\ ${ }^{2}$ Sheffield Hallam University, Sheffield, UK, United Kingdom
}

\begin{abstract}
Aim. The article deals with forecasting electrocardiogram changes (ECG) in athletes using stabilometric parameters. Materials and methods. 77 elite athletes aged 16-18 participated in the study (Candidate for Master of Sport, Master of sport: judo, taekwondo). To reveal cardiac conductivity disturbances and heart rhythm disorders, we used veloergometry. To assess postural balance, we used stabilometric equipment. Results. We registered incomplete right bundle branch block (IRBBB) in 5 athletes $(22.72 \%)$, extrasystoles - in 10 athletes $(45.45 \%)$, early repolarization syndrome (ERS) - in 3 athletes $(13.63 \%)$, sinoatrial block (SB) - in 2 athletes $(9.09 \%)$, pacemaker migration - in 2 athletes $(9.09 \%)$. The standard deviation of center of pressure (CoP) in the frontal plane in athletes with ECG changes in the natural standing position exceeded values of athletes without ECG changes by $94.93 \%$ with the eyes opened; by $121.09 \%$ with the head turned to the left; by $71.05 \%$ with the head turned to the left and the eyes closed; by $61.98 \%$ with the head turned to the right. We built a mathematical model. Conclusion. We studied the peculiarities of ECG changes in athletes. The parameters of stabilometry in athletes both with and without ECG changes were statistically significant $(p<0.05)$. With the help of stabilometric data, we created Random Forest model for forecasting possible ECG changes such as cardiac conductivity disturbances and heart rhythm disorders.
\end{abstract}

Keywords: postural balance, wrestlers, electrocardiogram, rhythm disorders, cardiac disturbances, forecasting.

Introduction. The importance of this problem is explained by the significant increase of heart rhythm disorders in athletes $[9,12]$. Changes in postural balance can be one of the reasons for rhythm disorders and cardiac conductivity disturbances in athletes. The postural disbalance of the muscular system can lead to the malfunction of vegetative structures [6]. According to the concept of visceral motor reflex connections, muscular and skeletal changes depend on non-specific brain structures $[3,5]$. There are almost no data, establishing connections between postural balance under physical loads and the development of locomotor system disorders in athletes or parallel pathologies in the heart and vegetative nervous system [11, 14-16].

Materials and methods. The study was conducted at the premises of SUSU Scientific and Research Center for Sports Science. 77 elite athletes aged 16-18 participated in the study during the recovery stage (Candidate for Master of Sport, Master of Sport: judo, taekwondo). To reveal cardiac conductivity disturbances and heart rhythm disorders, we used exercise tole- rance (SCHILLER AT-104) test according to the Bruce protocol 50/25 and $\mathrm{PWC}_{170}$ test [1]. We studied postural balance with the help of MBN Stabilo stabilometric system. We also used the system of assessment, which consists of 6 tests: head turns to the right and to the left with the eyes opened and closed [7]. We performed the statistical processing of the data obtained using Statistica V.10.0. software and $\mathrm{R}$ programming language.

Results. We registered incomplete right bundle branch block (IRBBB) in 5 athletes $(22.72 \%)$, which proves the dominance of the parasympathetic nervous system. During exercise tolerance test, we revealed extrasystoles in 10 athletes (45.45\%), which is possibly connected with the increase of the tone of the sympathetic nervous system. Early repolarization syndrome (ERS) was registered in 3 athletes (13.63\%) as a result of the increased tone of vagus nerve activity. We found sinoatrial block (SB) in 2 athletes $(9.09 \%)$. This can be the result of vegetative influences connected with the increased tone of the vagus nerve. We also registered pacemaker 


\section{Физиология}

migration in 2 athletes $(9.09 \%)$ as a result of the increased effect of the parasympathetic nervous system on the heart [2]. Therefore, among wrestlers, there is a predominance of athletes with the parasympathetic regulation of heart rhythm ( $54.53 \%$ compared to $45.45 \%$ ).

During the processing of the stabilometric data obtained, we divided athletes into 2 groups: athletes without $\mathrm{ECG}$ changes $-\mathrm{ECG}_{\text {norm }}(\mathrm{n}=55)$, athletes with $E C G$ changes $-\mathrm{ECG}_{\text {change }}(\mathrm{n}=22)$.

Table 1 demonstrates the stabilometric parameters of postural balance in the groups studied.

As follows from Table 1, the standard deviation of center of pressure $(\mathrm{CoP})$ in the frontal plane in $\mathrm{ECG}_{\text {change }}$ athletes exceeded values of $\mathrm{ECG}_{\text {norm }}$ athletes by $94.93 \%$ with the eyes opened; by $121.09 \%$ with the head turned to the left; by $71.05 \%$ with the head turned to the left and the eyes closed; by $61.98 \%$ with the head turned to the right and the eyes closed. Moreover, we registered a predominance of slow highamplitude oscillations $(0.40 \mathrm{~Hz})$ in $\mathrm{ECG}_{\text {change }}$ athletes in comparison with medium-amplitude oscillations $(0.51 \mathrm{~Hz})$ in $\mathrm{ECG}_{\text {norm }}$ athletes.

According to P.M. Gagey, oscillations of $0.40 \mathrm{~Hz}$ are represented by basic movements of center of pressure and adjusting movements and can be consciously controlled. Oscillations at $0.51 \mathrm{~Hz}$ are the result of muscle contractions, which are less subjected to conscious control. This means that, normally, the brain controls them automatically [12].

The sum of higher oscillations of center of pressure and their frequency characteristics is possibly connected with compensatory postural balance. The disturbances of tonic neck reflexes and cervical plexus innervation can lead to the disturbance of cerebral circulation and, thus, affect a vestibular function [11]. There is a possibility for further changes in the cardiac plexus as the nerve of the anterior mediastinum participates in the formation of a superficial cardiac-aortic plexus. This nerve provides the pericardium and heart with its fibers, provoking ECG changes [7].

In $\mathrm{ECG}_{\text {norm }}$ athletes the ratio of the length of the ellipse to its width was higher by $28.47 \%$ than in $\mathrm{ECG}_{\text {change }}$ athletes. Moreover, $\mathrm{ECG}_{\text {norm }}$ athletes possessed better values of LFS $90(1 / \mathrm{mm})$ in natural standing position with the eyes opened (56.48\% higher in comparison with $\mathrm{ECG}_{\text {change }}$ athletes) and with the head turned to the left (34.10\% higher). This means that in $\mathrm{ECG}_{\text {norm }}$ athletes there is a predominance of the stabilization of center of mass in the sagittal plane, which is responsible for the ankle strategy. In $\mathrm{ECG}_{\text {change }}$ athletes, there is a predominance of the stabilization of center of mass in the frontal plane, which is responsible for the hip strategy [8]. During the ankle strategy, calf muscles, especially the soleus, contract and compress the thin-walled veins, thereby helping the blood to return to the heart. This mechanism works due to small venous valves, which resist gravity and ensure blood circulation only to the heart [4]. Some authors characterize the soleus as 'the second heart' [15].

In case of the hip strategy there is an increase in the static tension of calf muscles, which results in the mechanical compression of vessels

Stabilometric parameters in wrestlers $(\mathrm{M} \pm \mathrm{m})$

Table 1

\begin{tabular}{|c|c|c|c|c|c|c|c|c|c|c|c|c|}
\hline $\begin{array}{l}\text { Para- } \\
\text { meters }\end{array}$ & go & $\lg 0$ & rgo & gz & $\lg z$ & $\operatorname{rgz}$ & go & $\lg 0$ & rgo & gz & $\lg z$ & rgz \\
\hline \multicolumn{7}{|c|}{ Without ECG changes (1) } & \multicolumn{6}{|c|}{ With ECG changes $(0)$} \\
\hline $\mathrm{X}(\mathrm{mm})$ & $\begin{array}{l}5,53 \pm \\
0,95^{*}\end{array}$ & $\begin{array}{l}6,40 \pm \\
0,83^{*}\end{array}$ & $\begin{array}{c}9,15 \pm \\
1,17\end{array}$ & $\begin{array}{c}10,42 \pm \\
2,55\end{array}$ & $\begin{array}{l}9,12 \pm \\
1,49^{*}\end{array}$ & $\begin{array}{c}11,26 \pm \\
1,78^{*}\end{array}$ & $\begin{array}{c}10,78 \pm \\
1,24 *\end{array}$ & $\begin{array}{c}14,05 \pm \\
3,91^{*}\end{array}$ & $\begin{array}{c}15,45 \pm \\
3,77\end{array}$ & $\begin{array}{c}14,07 \pm \\
1,65\end{array}$ & $\begin{array}{c}15,60 \pm \\
2,66^{*}\end{array}$ & $\begin{array}{c}18,24 \pm \\
2,58^{*}\end{array}$ \\
\hline $\begin{array}{l}\text { xf60 \% } \\
(\mathrm{Hz})\end{array}$ & $\begin{array}{l}0,51 \pm \\
0,05^{*}\end{array}$ & $\begin{array}{c}0,56 \pm \\
0,10\end{array}$ & $\begin{array}{c}0,47 \pm \\
0,03\end{array}$ & $\begin{array}{c}0,42 \pm \\
0,03\end{array}$ & $\begin{array}{c}0,42 \pm \\
0,04\end{array}$ & $\begin{array}{c}0,47 \pm \\
0,06\end{array}$ & $\begin{array}{l}0,40 \pm \\
0,05^{*}\end{array}$ & $\begin{array}{c}0,43 \pm \\
0,03\end{array}$ & $\begin{array}{c}0,41 \pm \\
0,04\end{array}$ & $\begin{array}{c}0,36 \pm \\
0,04\end{array}$ & $\begin{array}{c}0,34 \pm \\
0,03\end{array}$ & $\begin{array}{c}0,37 \pm \\
0,03\end{array}$ \\
\hline $\begin{array}{l}\text { LeWe } \\
\text { (u) }\end{array}$ & $\begin{array}{c}1,91 \pm \\
0,09\end{array}$ & $\begin{array}{c}1,71 \pm \\
0,07\end{array}$ & $\begin{array}{c}1,64 \pm \\
0,14\end{array}$ & $\begin{array}{c}1,91 \pm \\
0,18\end{array}$ & $\begin{array}{c}1,62 \pm \\
0,08\end{array}$ & $\begin{array}{l}1,85 \pm \\
0,12^{*}\end{array}$ & $\begin{array}{c}1,62 \pm \\
0,08\end{array}$ & $\begin{array}{c}1,67 \pm \\
0,21\end{array}$ & $\begin{array}{c}1,59 \pm \\
0,09\end{array}$ & $\begin{array}{c}1,65 \pm \\
0,16\end{array}$ & $\begin{array}{c}1,50 \pm \\
0,07\end{array}$ & $\begin{array}{l}1,44 \pm \\
0,07 *\end{array}$ \\
\hline $\begin{array}{l}\text { LFS 90, } \\
1 / \mathrm{mm}\end{array}$ & $\begin{array}{l}6,40 \pm \\
0,50 *\end{array}$ & $\begin{array}{c}6,56 \pm \\
0,45\end{array}$ & $\begin{array}{c}6,31 \pm \\
0,57\end{array}$ & $\begin{array}{c}5,55 \pm \\
0,44\end{array}$ & $\begin{array}{l}5,82 \pm \\
0,47 *\end{array}$ & $\begin{array}{c}5,17 \pm \\
0,40\end{array}$ & $\begin{array}{l}4,09 \pm \\
0,29 *\end{array}$ & $\begin{array}{c}5,04 \pm \\
0,45\end{array}$ & $\begin{array}{c}4,42 \pm \\
037\end{array}$ & $\begin{array}{c}4,39 \pm \\
0,41\end{array}$ & $\begin{array}{l}4,34 \pm \\
0,41^{*}\end{array}$ & $\begin{array}{c}4,28 \pm \\
0,34\end{array}$ \\
\hline
\end{tabular}

Note. X (mm) - standard deviation of center of pressure $(\mathrm{CoP})$ in the frontal plane; $x f 60 \%(\mathrm{~Hz})-60 \%$ of spectrum power in the frontal plane; LeWe $(\mathrm{u})$ - ratio of the length of the ellipse to its width; LFS $90,1 / \mathrm{mm}-$ ratio of the length of statokinesiogram to its S; go - natural standing position with the eyes opened; lgo - head turned to the left; rgo - head turned to the right; gz - natural standing position with the eyes closed; lgz - head turned to the left with the eyes closed; rgz - head turned to the right with the eyes closed; *statistically significant values $\mathrm{p}<0.05$. 
and impaired venous return [10]. Due to the lower involvement of calf muscles in maintaining center of pressure, the load is shifted to the front muscles of the thigh and core muscles, decreasing the efficiency of extracardiac circulation factors [13].

We built Random Forest model for wrestlers to forecast ECG changes using stabilometric parameters. The accuracy of the model allows us to register significant differences between samples, which can be used for forecasting (athletes with ECG changes/ athletes without ECG changes).

Figure 1 demonstrates the significance of stabilometric variables. To the left, there is a graph, explaining the contribution of a variable to the accuracy of the model. To the right, there is the graph of the purity of a branch without variable. The higher the variable, the more important it is for the model.

Figure 1 demonstrates that there are significant differences between the wrestlers of the samples studied. These differences allow us to forecast the result (rank). The distribution of differences is the following: Xgo; LFS90go; xf60go; Xrgz; LFS901gz; Xlgo; Xlgz.
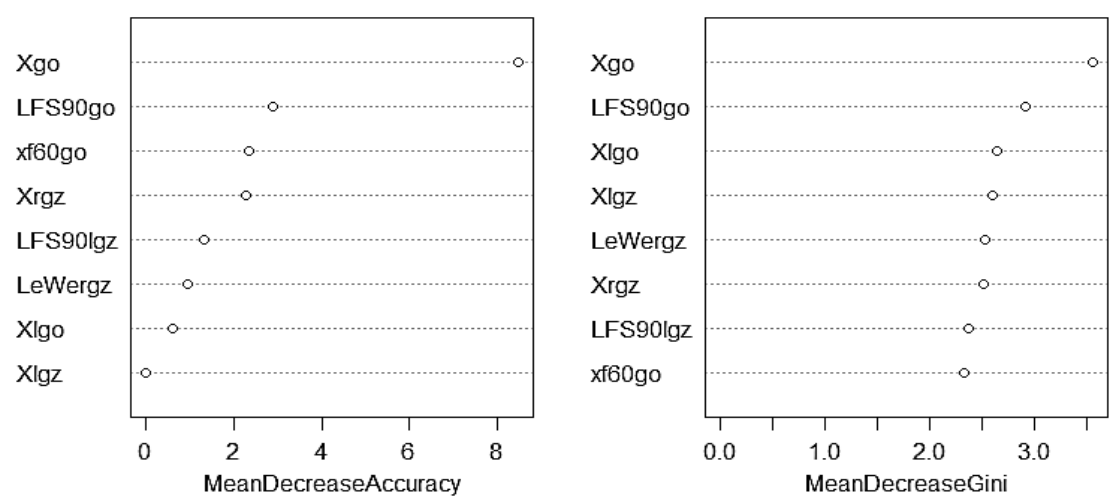

Fig. 1. Significance of variables

Variables of Random Forest model

Table 2

\begin{tabular}{|l|c|c|c|c|}
\hline \multicolumn{1}{|c|}{ Parameters } & ECG $_{\text {change }}$ & ECG $_{\text {norm }}$ & Mean Decrease Accuracy & Mean Decrease Gini \\
\hline Xgo & 7.3550051 & 6.80071913 & 8.47698018 & 3.564279 \\
\hline Xlgo & -0.2804205 & 1.43957532 & 0.61924602 & 2.649149 \\
\hline Xlgz & 0.3999397 & 0.05910775 & 0.01395987 & 2.607115 \\
\hline Xrgz & 3.8645389 & -0.47590629 & 2.27676686 & 2.511368 \\
\hline xf60go & 1.7124879 & 1.96296537 & 2.36550955 & 2.324428 \\
\hline LeWergz & 1.5798716 & -0.12561115 & 0.94311583 & 2.535156 \\
\hline LFS90go & 2.3222030 & 2.35919410 & 2.87898890 & 2.909770 \\
\hline LFS90lgz & 2.5251244 & -1.00522250 & 1.34569507 & 2.371643 \\
\hline
\end{tabular}

Note. Mean Decrease Accuracy - average accuracy of the model; Mean Decrease Gini - average decrease of Gini for this variable. 


\section{Физиология}

a decrease in the stability of the vertical position, misalignment of visual-motor and vestibularmotor connections, and an increase in the sensitivity of the proprioceptive apparatus. Using the results of stabilometry, we created a mathematical model, which allows us to predict ECG changes in wrestlers.

The article was supported by the government of the Russian Federation (Act No. 211 dd. 16.03.2013), Contract No. 02.A03.21.0011.

The study was performed as a part of the State Assignment of the Ministry of Education and Science of the Russian Federation (grant No. 19.9733.2017/БЧ).

\section{References}

1. Ar'kov V.V., Alfimov M.N. [Compensatory Mechanisms of Neuromuscular Imbalance Among Highly Qualified Athletes]. Biomeditsina [Biomedicine], 2011, no. 2, pp. 58-65. (in Russ.)

2. Mogendovich M.B. Fiziologicheskiye osnovy lechebnoy fizkul'tury [Physiological Basis of Physical Therapy]. Izhevsk, 1975. $199 \mathrm{p}$.

3. Savin A.A., Emel'yanova L.V. [The Influence of Acute Physical Fatigue on Stabilography Indicators in High-Class Wrestlers]. Izvestiya Yuzhnogo federal'nogo universiteta. Tekhnicheskiye nauki [Proceedings of the Southern Federal University. Technical science], 2010, vol. 110, no. 9, pp. 155-158.

4. Skvortsov D.V. Diagnostika dvigatel'noy patologii instrumental'nymi metodami: analiz pokhodki, stabilometriya [Diagnosis of Motor Pathology Using Instrumental Methods. Gait Analysis, Stabilometry]. Moscow, NMF MBN Publ., 2007. 640 p.

5. Terekhov A.V. [Adaptive Control in the System of Regulation of a Person's Vertical Posture]. Sistemy upravleniya i informatsionnyye tekhnologii [Control Systems and Information Technologies], 2006, no. 1 (23), pp. 287-290. (in Russ.)

6. 36th Bethesda Conference Eligibility Recommendations for Competitive Athletes with Cardiovascular Abnormalities. Journal of the American College of Cardiology, 2005, vol. 45 , no. 8 , p. 15.

7. Angyan L., Teczely T., Angyan Z. Factors Affecting Postural Stability of Healthy Young Adults. Acta Physiol. Hung, 2007, vol. 94, pp. 289-299. DOI: 10.1556/APhysiol.94. 2007.4.1

8. Ashton-Miller J.A., Howard D. The Functional Anatomy of the Female Pelvic Floor and Stress Continence Control System. Scand J. Urol Nephrol, 2001, suppl.207, pp.1-7. DOI: 10.1080/003655901750174773

9. Corrado D., Pelliccia A., Heidbuchel H. Recommendations for Interpretation of 12-Lead Electrocardiogram in the Athlete. European Heart Journal, 2010, no. 31 (2), pp. 243-259.

10. Epishev V.V., Ryabina K.E., Isayev A.P., Erlikh V.V. [Postural Balance of Middle-Distance Runner-Athletes]. Rossiyskiy zhurnal biomekhaniki [Russian Journal of Biomechanics], 2017, vol. 21, no. 2, pp. 166-177. (in Russ.)

11. Epishev V., Korableva J., Antonenko E., Khusnutdinova A. ECG Changes in Young Athletes in Russia. 2018 6th International Conference on Physical Education and Society Management (ICPESM 2018), London, UK. 2018, vol. 94, pp. 386-392. DOI: $10.26602 / \mathrm{lnms} .2018 .94 .386$

12. Gagey P.M., Weber B. A Distinct Clinical Syndrome Defining the Postural Patient. Gait\&Posture, 2005, vol. 21, no. 1, p. 121.

13. Imamura K., Mano T. Role of Postural Sway as a Compensatory Mechanism for Gravitational Stressonthe Cardiovascular System. Gait\&Posture, 1999, vol. 1, no. 9, p. 5.

14. Kabacoff R.I. R in Action. Pataanalysis and Graphics with R. Island: Manning Publication, $2015.279 \mathrm{p}$.

15. Nazarenko A.S., Chinkin A.S. Cardiovascular, Impellent and Sensory Reactions of Various Specializations Athletes on Vestibular Irritation. Human Physiology, 2011, no. 6, pp. 726-732. DOI: 10.1134/S0362119711050161

16. Semchenko A.A., Nenasheva A.V. Assessment of the Functional Capacity of the Heart in Hurdlers Within the System of Training-Competitive Conditioning. Minerva Ortopedica $e$ Traumatologica, 2018, vol. 69, no. 3, pp. 7-10. 


\title{
ВЛИЯНИЕ ПОСТУРАЛЬНОГО БАЛАНСА НА ИЗМЕНЕНИЕ ЭЛЕКТРОКАРДИОГРАФИЧЕСКИХ ПОКАЗАТЕЛЕЙ ЕДИНОБОРЦЕВ
}

\author{
В.В. Эрлих ${ }^{1}$, Ю.Б. Кораблева ${ }^{1}$, В.В. Епишев ${ }^{1}$, О. Полякова ${ }^{2}$ \\ ${ }^{1}$ Южно-Уральский государственный университет, г. Челябинск, Россия, \\ ${ }^{2}$ Университет Шефрфилда Халлама, г. Шефрфилд, Великобритания
}

\begin{abstract}
Цель исследования - прогнозирование изменений на электрокардиограмме (ЭКГ) спортсменов посредством стабилометрических показателей. Организация и методы исследования. Исследовали 77 элитных спортсмена (КСМ, МС: дзюдо, тхэквондо, возраст 16-18 лет). Для выявления нарушений ритма и проводимости применяли велоэргометрию, для оценки постурального баланса - стабилометрический комплекс. Результаты. Неполная блокада правой ножки пучка Гиса (НБПНПГ) наблюдалась у 5 спортсменов (22,72 \%), экстрасистолы - у 10 (45,45 \%), синдром ранней реполяризации (СРР) - у 3 (13,63 \%), синоаурикулярная блокада (СА) - у двух $(9,09 \%)$, миграция водителя ритма - 2 (9,09\%). Среднеквадратическое отклонение общего центра давления (ОЦД) во фронтальной плоскости у спортсменов с изменениями на ЭКГ при основной стойке (О.С.) - глаза открыты (ГО) на 94,93 \% превышало значения спортсменов без изменений на ЭКГ; при повороте головы влево - на 121,09 \%; при повороте головы влево, глаза закрыты (ГЗ) - на 71,05 \%; при повороте головы вправо (ГЗ) - на 61,98 \%. Построена математическая модель. Заключение. Были рассмотрены особенности изменений электрокардиограммы спортсменов. Параметры стабилометрии атлетов с изменениями ЭКГ и без были достоверно значимы $(\mathrm{p}<0,05)$. Построена модель Random Forest (RF - модель случайного леса) для прогнозирования возможных изменений ЭКГ спортсменов в виде нарушений ритма и проводимости посредством стабилометрических показателей.
\end{abstract}

Ключевые слова: постуральный баланс, единобориы, электрокардиограмма, нарушения ритма, нарущения проводимости, прогнозирование.

\section{Литература}

1. Арьков, В.В. Компенсаторные механизмы нервно-мылечного дисбаланса у спортсменов высокой квалификации / В.В. Арьков, М.Н. Алфимов // Биомедииина. - 2011. - № 2. - С. 58-65.

2. Могендович, М.Б. Физиологические основы лечебной физкультуры / М.Б. Могендович. Ижевск, 1975. - 199 с.

3. Савин, А.А. Влияние острого физического утомления на показатели стабилографии у бориов высокого класса / А.А. Савин, Л.В. Емельянова // Известия Южного федерального университета. Технические науки. - 2010. - Т. 110, № 9. - С. 155-158.

4. Сквориов, Д.В. Диагностика двигательной патологии инструментальными методами: анализ походки, стабилометрия / Д.В. Сквориов. - М.: НМФ МБН, 2007. - 640 c.

5. Терехов, А.В. Математическое моделирование регуляции позы человека: автореф.: 01.02.01 / A.B. Терехов. - М.: МГУ, 2007. -25 c.

6. 36th Bethesda Conference Eligibility Recommendations for Competitive Athletes with Cardiovascular Abnormalities // Journal of the American College of Cardiology. - 2005. - Vol. 45, № 8. - 15 p.

7. Angyan, L. Factors affecting postural stability of healthy young adults / L. Angyan, T. Teczely, Z. Angyan // Acta Physiol. Hung. - 2007. - Vol. 94. - P. 289-299.

8. Ashton-Miller, J.A. The functional anatomy of the female pelvic floor and stress continence control system / J.A. Ashton-Miller, D. Howard // Scand J. Urol Nephrol. - 2001. - Suppl. 207. - P. 1-7.

9. Corrado, D. Recommendations for interpretation of 12-lead electrocardiogram in the athlete / D. Corrado, A. Pelliccia, H. Heidbuchel // European Heart Journal. - 2010. - № 31 (2). - P. 243-259.

10. Епишев, В.В. Постуральный баланс у легкоатлетов-бегунов на средние дистаниии / В.В. Епишев, К.Е. Рябина, А.П. Исаев, В.В. Эрлих // Российский журнал биомеханики. - 2017. T. 21, № 2. - C. 166-177. 


\section{Физиология}

11. Epishev, V. ECG Changes in Young Athletes in Russia / V. Epishev, J. Korableva, E. Antonenko, A. Khusnutdinova // 2018 6th International Conference on Physical Education and Society Management (ICPESM 2018), July 22-24, 2018, London, UK. - 2018 - Vol. 94. - P. 386-392. DOI: 10.26602/lnms.2018.94.386

12. Gagey, P.M. A distinct clinical syndrome defining the postural patient / P.M. Gagey, B. Weber // Gait\&Posture. - 2005. - Vol. 21, № 1. - P. 121.

13. Imamura, K. Role of postural sway as a compensatory mechanism for gravitational stress on the cardiovascular system / K. Imamura, T. Mano // Gait\&Posture. - 1999. - Vol. 1, № 9. - P. 5.

14. Kabacoff, R.I. R in action. Pataanalysis and graphics with R / R.I. Kabacoff. - Island: Manning Publication, 2015. - P. 279.

15. Nazarenko, A.S. Cardiovascular, impellent and sensory reactions of various specializations athletes on vestibular irritation / A.S. Nazarenko, A.S. Chinkin // Human Physiology. - 2011. - № 6. P. 726-732.

16. Semchenko, A.A. Assessment of the functional capacity of the heart in hurdlers within the system of training-competitive conditioning / A.A. Semchenko, A.V. Nenasheva // Minerva Ortopedica e Traumatologica. - 2018. - Vol. 69, № 3. - P. 7-10.

Эрлих Вадим Викторович, директор института спорта, туризма и сервиса, Южно-Уральский государственный университет. 454080, г. Челябинск, проспект Ленина, 76. E-mail: erlikhvv@susu.ru, ORCID: 0000-0003-4416-1925.

Кораблева Юлия Борисовна, лаборант научно-исследовательского центра спортивной науки, преподаватель кафедры физического воспитания и здоровья института спорта, туризма и сервиса, Южно-Уральский государственный университет. 454080, г. Челябинск, проспект Ленина, 76. E-mail: julya-74@yandex.ru, ORCID: 0000-0003-2337-3531.

Епишев Виталий Викторович, директор научно-исследовательского центра спортивной науки, доцент кафедры теории и методики физической культуры и спорта института спорта, туризма и сервиса, Южно-Уральский государственный университет. 454080, г. Челябинск, проспект Ленина, 76. E-mail: epishev74@mail.ru, ORCID: 0000-0002-7284-7388.

Полякова Ольга, руководитель курса «Спортивный бизнес и менеджмент» Факультета здоровья и благополучия, Университет Шеффилда Халлама. S1 1WB, Великобритания, г. Шеффилд, ул. Ховарда, 36. E-mail: O.Polyakova@shu.ac.uk, ORCID: 0000-0002-6947-2394.

Поступила в редакцию 30 ноября 2018 г.

\section{ОБРАЗЕЦ ЦИТИРОВАНИЯ}

Effect of Postural Balance on Changes in the Electrocardiography Parameters of Wrestlers / V.V. Erlikh, Yu.B. Korableva, V.V. Epishev, O. Polyakova // Человек. Спорт. Медицина. - 2018. - Т. 18, № S. - C. 13-18. DOI: $10.14529 / \mathrm{hsm} 18 \mathrm{~s} 02$

\section{FOR CITATION}

Erlikh V.V., Korableva Yu.B., Epishev V.V., Polyakova O. Effect of Postural Balance on Changes in the Electrocardiography Parameters of Wrestlers. Human. Sport. Medicine, 2018, vol. 18, no. S, pp. 13-18. DOI: $10.14529 / \mathrm{hsm} 18 \mathrm{~s} 02$ 